\title{
LONG -TERM BEHAVIOR OF SILICA FUME CONCRETE 、 EXPOSED TO DIFFERENT AGGRESSIVE MEDIA
}

\author{
M.M. El-Aiat, M.M.Balaha, and \\ A.G. Abdel-Rahman \\ Materials Dept., Faculty of Engineering \\ Zagazig University, EGYPT
}

\author{
H.E. Anwar \\ Industrial Technical Institute. \\ Zagazig, Egypt
}

\begin{abstract}
The durability of high strength concrete (HSC) was experimentally investigated in terms of compressive, tensile and bond strengths. The effect of curing media, (air and tap water) and the effect of emersion in sea- water were taken into consideration. The silica fume (SF) concrete specimens were exposed directly to two types of environmental attack (sodium sulphate and sodium chloride). The specimens were submerged in two different solutions of sodium sulphate having concentrations of $5 \%$ and $7 \%$ and sodium chloride of $2 \%$ and $4 \%$ concentrations. The specimens were tested after $28,360,540$ and 720 days. The SF addition was $10 \%$ by weight of cement. Test results showed that the compressive, tensile and bond strengths generally increase, with higher early age strength and higher early rate of strength gain, with time up to about two years. High strength concrete, incorporating silica fume, when exposed to sulphate and chloride solutions, exhibits highest values, higher rates of increase and the lowest rates of decrease of compressive strength up to 24 months. X-ray diffraction (XRD) patterns of the hardened specimens were plotted for all cured conditions, which explain the chemical compounds formed after hardening.

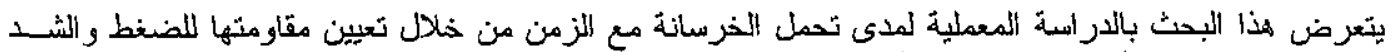

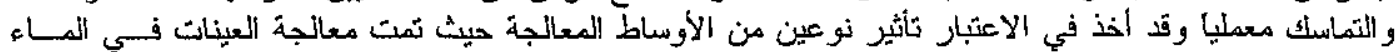

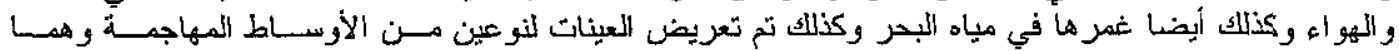

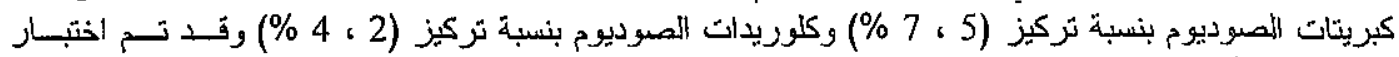

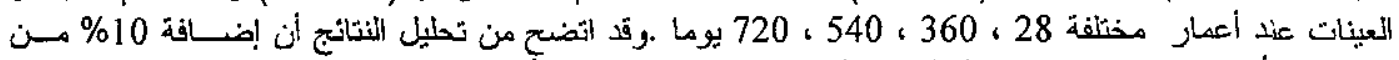

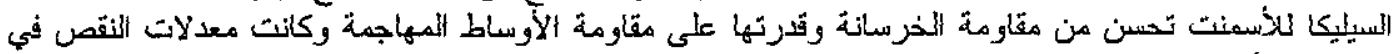

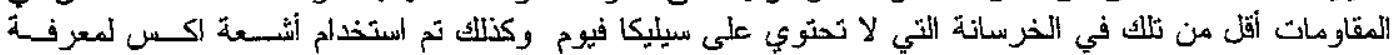

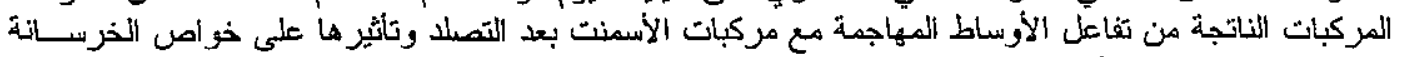

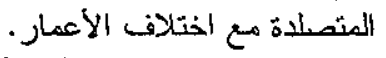

Keywords: Durability, Concrete Strength, Aggressive Media, X-Ray Diffraction.

\section{INTRODUCTION}

Chemical attack by aggressive water is one of the factors responsible for damage of concrete. The presence of sulphate and chloride ions in water accounts for its aggressive behaviour to concrete because certain constituents of the cement paste can enter into deleterious chemical reactions with sulphates. Sea- water, ground water containing soluble alkali sulphates and also many industrial water containing enough sulphate are to be potentially damaging Portland cement concrete $[1,2,3,4,5,6]$.

Deterioration of concrete in contact with sulphate or chloride bearing water has been studied for sometime. Concrete corrosion can be classified into three types i- Leaching of free lime. ii- Exchange corrosion of readily soluble substances. iii- Corrosion by expansion accompanying chemical reaction $[7,8]$. The deterioration of concrete structural components exposed to marine environments or placed in soils and ground water contaminated with sulphate salts is common. The sulphate ions react with the hydration products of cement, namely $\mathrm{C}_{3} \mathrm{~A}$ and $\mathrm{Ca}(\mathrm{OH})_{2}$, to produce expansive and/or softening types of deterioration. The increase in the $\mathrm{C}_{3} \mathrm{~S} / \mathrm{C}_{2} \mathrm{~S}$ ratio results in an increased calcium hydroxide content in the hardened cement concrete, thereby enhancing the susceptibility of such cements to the softening type deterioration of sulphate attack [9].

The durability of concrete in sulphate environment depends on several factors, such as the permeability of the concrete, the type of structure, the concentration and type of sulphate, the water table 
and the mobility of the ground water. The reduced permeability of silica fume concrete would be expected to reduce the transportation of sulphate ions into concrete. Since silica fume replacement levels are generally 15 percent or less, the dilution effect on $\mathrm{C}_{3} \mathrm{~A}$ would be small. In this case, the performance of concrete with a conventional Portland cement and a 15 percent silica fume addition with a water to cementitious materials ratio of 0.62 was equal to that of a sulphate resistance Portland cement concrete with a water cement ratio of $0.50[10,11]$.

On the other hand, the sulphate attack on concrete is a complex phenomenon, where chemical and physical aspects should be considered. Sulphate of various bases attack harderled cements very markedly. Magnesium, sodium, potassium, ammonium and various other sulphates react both with the free calcium hydroxide in a set cement to form a calcium sulphate, and with the hydrated calcium aluminates to form the more insoluble calcium sulphoaluminate hydrates $[12,13]$. The reactions with sodium sulphate, for example, can be formulated as:

$$
\begin{aligned}
& \mathrm{Ca}(\mathrm{OH})_{2}+\mathrm{Na}_{2} \mathrm{SO}_{4} \cdot 10 \mathrm{H}_{2} \mathrm{O} \longrightarrow \mathrm{CaSO}_{4} \cdot 2 \mathrm{H}_{2} \mathrm{O}+ \\
& 2 \mathrm{NaOH}+8 \mathrm{H}_{2} \mathrm{O} \\
& 3 \mathrm{CaO} \cdot \mathrm{Al}_{2} \mathrm{O}_{3} \cdot 12 \mathrm{H}_{2} \mathrm{O}+3\left(\mathrm{CaSO}_{4} \cdot 2 \mathrm{H}_{2} \mathrm{O}\right)+13 \mathrm{H}_{2} \mathrm{O} \\
& \longrightarrow 3 \mathrm{CaO} \cdot \mathrm{Al}_{2} \mathrm{O}_{3} \cdot 3 \mathrm{CaSO}_{4} \cdot 31 \mathrm{H}_{2} \mathrm{O}
\end{aligned}
$$

Gypsum and ettringite are produced by chemical reactions of sulphate and $\mathrm{Ca}(\mathrm{OH})_{2}, \mathrm{C}_{3} \mathrm{~A}$. Formation of gypsum results in softening and damaging of material. There is close relationship between the $\mathrm{Ca}(\mathrm{OH})_{2}$ content and gypsum formation. Ettringite formation results in cracking and expansion of the material, as a result of the water absorption of crystalline ettringite $[14,15,16]$.

In this investigation, the long term behavior of high strength concrete (HSC) subjected to different aggressive attack was experimentally investigated. The evaluation was based on the measurements of the mechanical properties (compressive, tensile and bond strengths). Also X-ray diffraction (XRD) technique was used to identify the hydrated products and correlate both the microstructure and mechanical properties.

\section{EXPERIMENTAL PROGRAM}

About 327 specimens were cast and tested at different ages $(28,360,540$, and 720 days) to study the long-term behavior of silica fume concrete cured in different media (air, tap water and sea water) and exposed to different aggressive media (sodium chloride and sodium sulphate). The behavior of SF concrete was studied in terms of compressive, tensile and bond strength as reported in Table 1.

Type I ordinary Portland cement (Egyptian cement company, Suez) meeting the requirements of E.S. $373 / 1991$ was used. The cement content was constant for all mixes and equal to $500 \mathrm{~kg} / \mathrm{m}^{3}$.
Crushed dolomite with nominal maximum size of 14 $\mathrm{mm}$ was used as coarse aggregate. The crushed stone particles had different colors that varied between cream and deep cream. The particles were irregular in shape and had a granular-porous texture. Natural fine clean sand free from any impurities such as silt, clay and organic compounds were used as fine aggregate. Tap water has been used for mixing and curing works. The water cementitious ratio was 0.295 . The aggressive media were sodium chloride with concentrations of 2 and $4 \%$ and sodium sulphate with concentrations of 5 and $7 \%$.

One type of admixtures was used in concrete mixes, which is classified as high range water reducer (HRWR) meeting the requirements of ASTM C49481 type F. Silica fume used in concrete mixes have specific surface area of $16.8 \mathrm{~m}^{2} / \mathrm{gm}$ and specific gravity of 2.20 . Silica fume has been used in concrete mixes as an addition. Silica fume was added with dosage of $10 \%$ by weight of cement. High tensile steel (deformed bars) of $3600 \mathrm{~kg} / \mathrm{cm}^{2}$ yield stress and $6100 \mathrm{~kg} / \mathrm{cm}^{2}$ tensile strength was used in pullout specimens. Many trials had been made to find out the most suitable mix proportions taking into consideration the previous results in the literature. Cubes with $150 \mathrm{~mm}$ side length were used as compression test specimens, cylinders $150 \mathrm{~mm}$ diameter and $300 \mathrm{~mm}$ height were used as indirect tension and pull-out test specimens. Hydraulic testing machine of 300 tons capacity was used to determine the compressive strength while hydraulic testing machine of 100 tons capacity was used to determine the tensile and bond strengths. For XRD analysis, different samples representing all mixes were collected and sieved through a $75 \mu \mathrm{m}$ sieve (No. 200) to remove the bulk of sand grains. Finally, the samples were ground to pass through $45 \mu \mathrm{m}$ sieve (No. 325) and stored in desiccators to prevent carbonation before X-ray diffraction (XRD) analysis.

\section{RESULTS AND DISCUSSIONS}

The behavior of SF concrete was studied up to 720 days in terms of compressive, tensile and bond strengths as follows:

\section{Compressive Strength}

The compressive strength results of SF concrete, with silica fume addition of $10 \%$ by weight of cement, cured in tap water, atmospheric air, sea water and $2 \%$ $\mathrm{Cl}^{-}, 4 \% \mathrm{Cl}^{-}, 5 \% \mathrm{SO}_{4}^{-}$and $7 \% \mathrm{SO}_{4}^{-}$solutions for 28 , 360,540 , and 720 days, are graphically represented in Fig. 1. It can be noticed that the concrete compressive strength increases with time for all samples by different rates and net at the early ages. 
Table 1: Experimental Program

a)

\begin{tabular}{|c|c|c|c|c|c|c|c|c|c|c|c|c|}
\hline \multirow{4}{*}{ Specimen } & \multicolumn{12}{|c|}{ Curing media } \\
\hline & \multicolumn{4}{|c|}{ Atmospheric air } & \multicolumn{4}{|c|}{ Tap water } & \multicolumn{4}{|c|}{ Sea water } \\
\hline & \multicolumn{12}{|c|}{ Curing Age, Days } \\
\hline & 28 & 360 & 540 & 720 & 28 & 360 & 540 & 720 & 28 & 360 & 540 & 720 \\
\hline Compression test & $E$ & {[} & 5 & D & $\ddot{\square}$ & $!$ & $?$ & 11 & 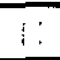 & $: \vdots$ & $\because$ & \\
\hline Pull out test & $\ddot{L}$ & L] & $ت$ & [] & U & $\because \cdots$ & $\ddot{a}$ & $i j$ & - & $-\cdots$ & -- & - \\
\hline Indirect tension test & $\square$ & 口] & 口 & $\square$ & $\square$ & 七 & 4 & $\because$ & ? & I. & $\bar{i}$ & ii \\
\hline
\end{tabular}

b)

\begin{tabular}{|c|c|c|c|c|c|c|c|c|c|c|c|c|c|c|c|c|}
\hline \multirow{4}{*}{ Specimen } & \multicolumn{16}{|c|}{ Aggressive media $\left(\mathrm{Cl}^{-}\right)$} \\
\hline & \multicolumn{4}{|c|}{$2 \% \mathrm{CL}$} & \multicolumn{4}{|c|}{$4 \% \mathrm{CL}^{-}$} & \multicolumn{4}{|c|}{$5 \% \mathrm{SO}_{4}^{--}$} & \multicolumn{4}{|c|}{$7 \% \mathrm{SO}_{4}^{--}$} \\
\hline & \multicolumn{16}{|c|}{ Curing age, days } \\
\hline & 28 & 360 & 540 & 720 & 28 & 360 & 540 & 720 & 28 & 360 & 540 & 720 & 28 & 360 & 540 & 720 \\
\hline Compression test & 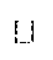 & $\Xi$ & $\therefore$ & $r$ & $1 .:$ & $\cdots$ & $i$ & r: & $1 ;$ & $\therefore$ & $\vdots:$ & & $i$ & & & \\
\hline Pull out test & $\therefore$ & $\mathrm{L}$ & $i$ & $\cdots$ & :.. & L & & . & $\sim$ & - & - & - & - & - & - & - \\
\hline $\begin{array}{l}\text { Indirect tension } \\
\text { test }\end{array}$ & {$[]$.} & 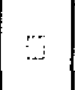 & $j$ & $\sqcup$ & Ll & 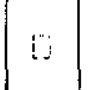 & $\lceil\mathrm{I}$ & Г.. & $i j$ & & 11 & 1! & : : & $! !$ & i & \\
\hline
\end{tabular}

The rate of compressive strength gain with time as a ratio of the strength at 28 days curing age $\left(f c / f c_{28} \%\right)$ increased with time up to 720 days, after 360 days these rates gradually reduced for all media, but the reduction was lower in case of reference media (tap water and air) compared to the aggressive ones, as plotted in Fig. 2.

The ratio of compressive strength gain with time as a ratio of the strength at 28 days curing age $\left(\mathrm{fc} / f c_{\mathrm{w}} \%\right)$ decreased as the aggressive ion intensity increased, and increased with time in chloride media up to 540 days then decreased, Fig. 3. The ratio of $\left(f c / f c_{w} \%\right)$ decreased with increasing curing age in air and sulphate media but increased with curing age in seawater up to 360 days then decreased. These ratios $\left(f c / f c_{1} \%\right)$ reached about $9.3,14.8,18.1$ and 19.8 in air, $4 \% \mathrm{Cl}^{-}, 7 \% \mathrm{SO}_{4}^{--}$solutions, and sea-water, respectively. The resistance of silica fume blended cement to sulphate attack was attributed to the formation of fine pore structure, reducing of lime content with a parallel decrease of the $\mathrm{Ca} / \mathrm{Si}$ ratio of the CSH. Also when SF concrete is exposed to sodium chloride solutions, durability of concrete is enhanced due to the reaction of liberated lime with silica fume forming $\mathrm{CSH}$, which deposited in the pores of the cement pastes, therefore, the penetration of the chloride ions through the concrete is delayed and the compressive strength increases.

\section{Indirect Tensile Strength}

Test results of splitting tensile strength for HSC, with $10 \%$ silica fume addition cured in tap water, atmospheric air, and $2 \% \mathrm{Cl}^{-}, 4 \% \mathrm{Cl}^{-}, 5 \% \mathrm{SO}_{4}^{-}, 7 \%$ $\mathrm{SO}_{4}^{-}$solutions, and sea-water for $28,360,540$, and 720 days, are graphically represented in Fig. 4 . The figure explained that the splitting tensile strength of concrete increases upon increasing curing age for all samples with different rates.

The rate of enhancement in the tensile strength with time as a ratio of the strength at 28 days curing age $\left(f t / f t_{28} \%\right)$ increased with time up to 540 days. Above 540 days, the tensile strength ratio for specimens exposed to $4 \% \mathrm{Cl}$, sea-water and $7 \% \mathrm{SO}_{4}$ decreased. For specimens submerged in other media (tap water, air, $2 \% \mathrm{Cl}$ and $5 \% \mathrm{SO}_{4}$ ), the tensile strength ratio still increased but with a lower rate compared to those measured before 540 days as shown in Fig. 5 .

The ratio of tensile strength $\left(f t / f_{t, 1} \%\right)$ decreased as the aggressive ion intensity increased, and also decreased with increasing curing age, as represented in Fig. 6 . This ratio $\left(f t / f t_{w} \%\right)$ reached about $9.4,13.3,14.1$ and 15.6 in air, $4 \% \mathrm{Cl}^{-}, 7 \% \mathrm{SO}_{4}^{-}$solutions, and seawater, respectively. 


\section{Bond Strength}

Pull-out test results for HSC, with the addition of $10 \%$ silica fume cured in tap water, atmospheric air, $2 \% \mathrm{Cl}$, and $4 \% \mathrm{Cl}$ solutions, for $28,360,540$, and 720 days, are graphically represented in Fig. 7. It can be noticed from the figure that the concrete bond strength increases with increasing curing age for all samples by different rates. The rate of increase in bond strength with time as a ratio of the strength at 28 days curing age $\left(f b / f b_{28} \%\right)$ increased with time up to 720 days, with a decreasing rate depending on the storage media as shown Fig. 8. The presence of SF improves the bond especially at early ages because $\mathrm{Ca}(\mathrm{OH})_{2}$ and $\mathrm{CaCO}_{3}$ decreases with the addition of silica fume due to the higher pozzolanic activity of silica fume, which reacts with $\mathrm{Ca}(\mathrm{OH})_{2}$ and forms $\mathrm{CSH}$. The presence of SF affected the morphology and microstructure of the steel-cement paste transition zone, the compressive strength, which plays a major role in the pullout strength. The pullout strength for the deformed bars was also affected by the tensile strength of concrete.

The bond strength ratio $\left(f b / f b_{i v} \%\right)$ decreases, as the aggressive ion intensity increases. Also it decreases with increasing curing age, Fig. 9. This ratio $\left(f b / f b_{w} \%\right)$ reached about $3.5,4.1$ and 10.5 , respectively, in air, $2 \% \mathrm{Cl}$, and $4 \% \mathrm{Cl}^{-}$solutions.

\section{XRD patterns}

The X-ray diffraction patterns (XRD) of the hardened specimens cured in sulphate solutions for long duration are given in Figs. 10 and 11. It is found that the peaks of $\mathrm{Ca}(\mathrm{OH})_{2}$ decrease with time, due to the chemical reactions of sodium sulphate and $\mathrm{Ca}(\mathrm{OH})_{2}$, where ettringite are produced. The peaks of $\mathrm{CSH}$ and ettringite are detected; its peak intensities are slightly increased with time. Also, it is found that the peaks of $\mathrm{CaCO}_{3}$ decrease with time.

The X-ray diffraction patterns of the hardened specimens cured in chloride solutions for long duration are given in Figs. 12 and 13. It is found that the peaks of $\mathrm{Ca}(\mathrm{OH})_{2}$ decrease with time, due to the chemical reactions of sodium chloride and $\mathrm{Ca}(\mathrm{OH})_{2}$, where calcium chloroaluminate hydrate are produced. The peaks of $\mathrm{CSH}$ and calcium chloroaluminate hydrate are detected; these peak intensities are slightly increased with time. Also, it is found that the peaks of $\mathrm{CaCO}_{3}$ decrease with time.

The X-ray diffraction patterns of the hardened specimens cured in sea-water for long duration are given in Fig. 14. It is found that the peaks of $\mathrm{Ca}(\mathrm{OH})_{2}$ decrease with time, due to the chemical reactions of sulphates and chlorides with $\mathrm{Ca}(\mathrm{OH})_{2}$, where ettringite and calcium chloroaluminate hydrate are produced. The peaks of $\mathrm{CSH}$, ettringite, and calcium chloroaluminate hydrate are detected; these peak intensities are slightly increased with time. Also, it is found that the peaks of $\mathrm{CaCO}_{3}$ decrease with time.

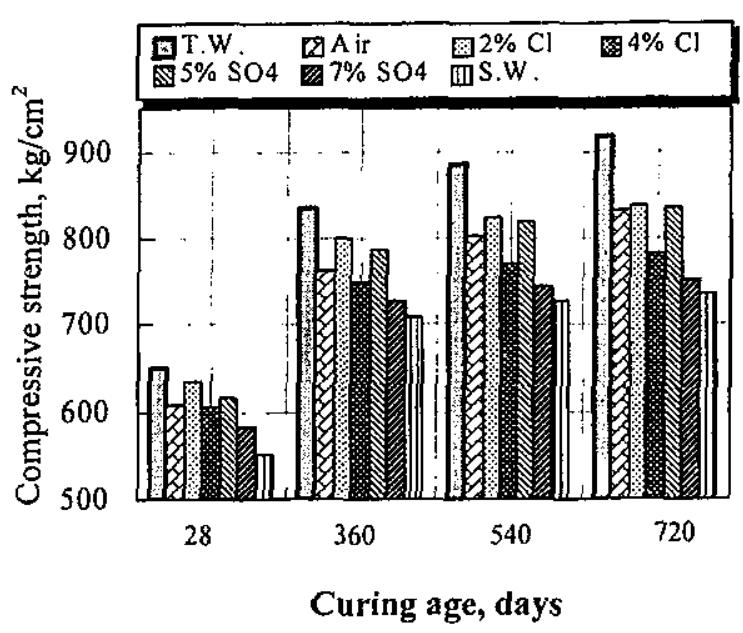

Fig. 1 Compressive strength of HSC samples, with $10 \%$ SF addition cured in different media for long duration.

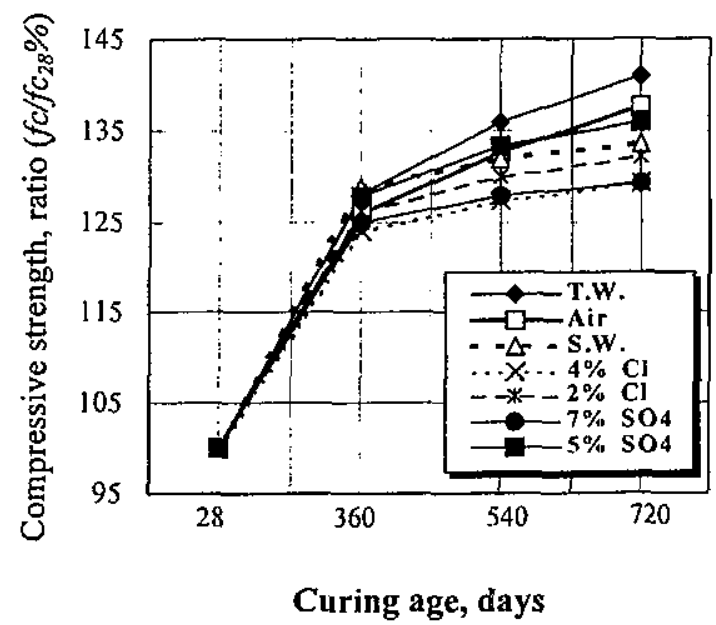

Fig. 2 Rate of change in compressive strength of HSC $\left(f \mathcal{c} / f_{28} \%\right)$ samples, cured in different media for long duration.

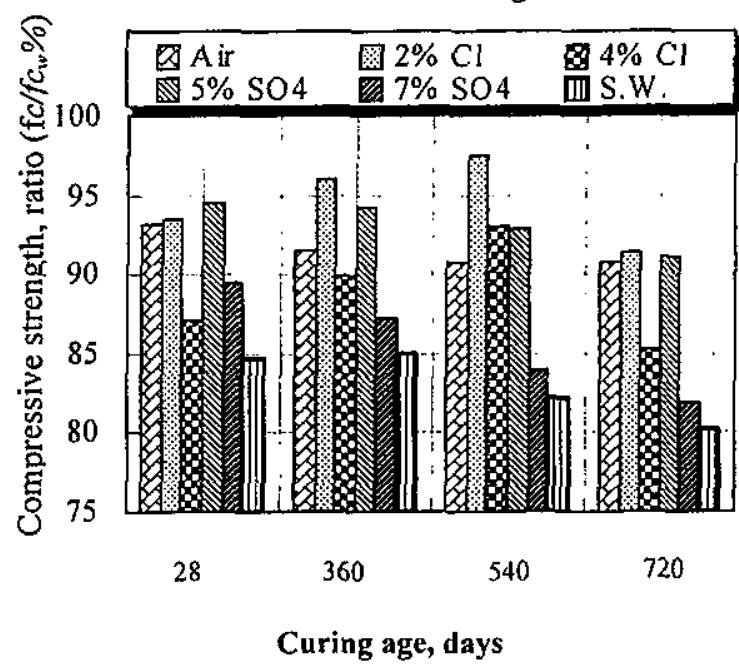

Fig. 3 Rate of change in compressive strength of HSC $\left(f c / f c_{w} \%\right)$ samples, with $10 \% \mathrm{SF}$ addition cured in different media for long duration. 


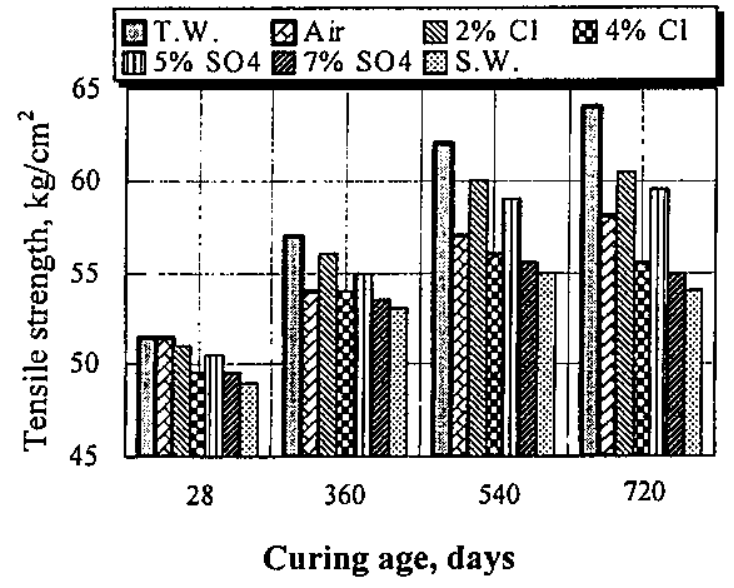

Fig. 4 Tensile strength of HSC samples, with $10 \% \mathrm{SF}$ addition cured in different media for long duration.

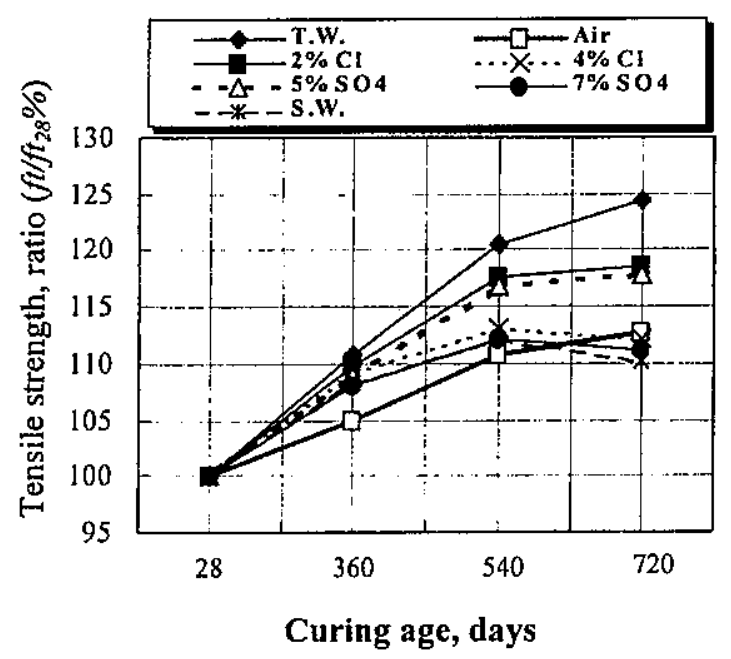

Fig. 5 Rate of change in tensile strength of HSC $\left(f t / f_{28} \%\right)$ samples, with $10 \% \quad \mathrm{SF}$ addition cured in different media for long duration.

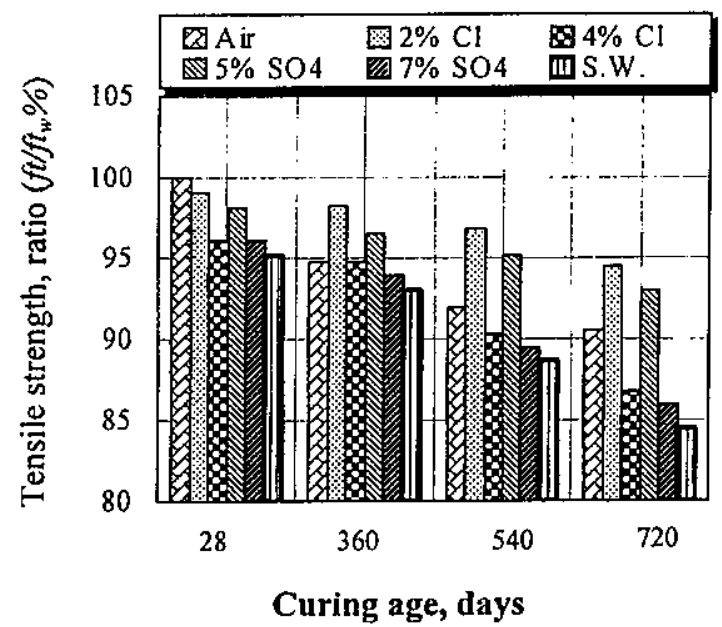

Fig. 6 Rate of change in tensile strength of HSC $\left(f t / f t_{w} \%\right)$ samples, with $10 \% \mathrm{SF}$ addition cured in different media for long duration.

Engineering Research Journal, Minoufiya University, Vol.28, No.3, July 2005

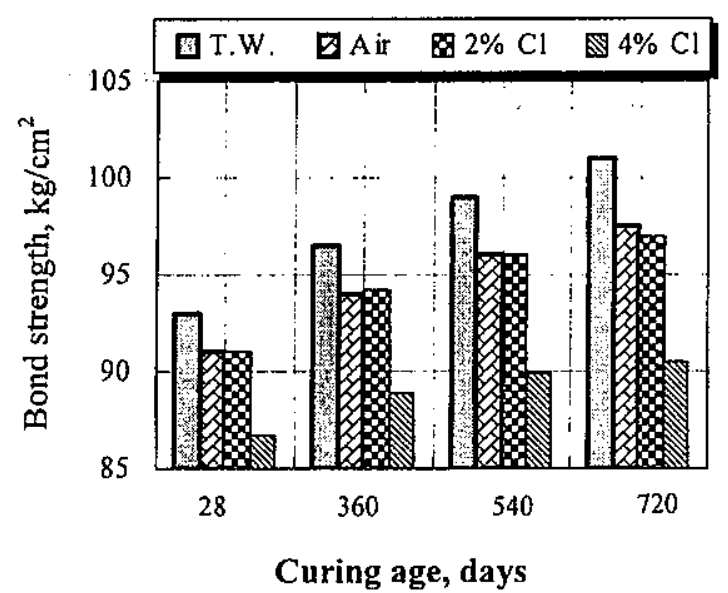

Fig. 7 Bond strength of HSC samples, with $10 \%$ $\mathrm{SF}$ addition cured in different media for long duration.

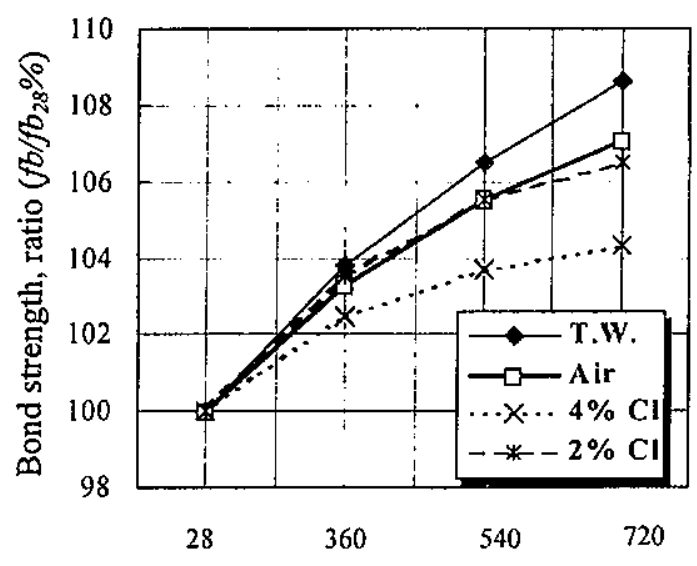

Curing age, days

Fig. 8 Rate of change in bond strength of HSC $\left(f b / f b_{28} \%\right)$ samples, with $10 \%$ SF addition cured in different media for long duration.

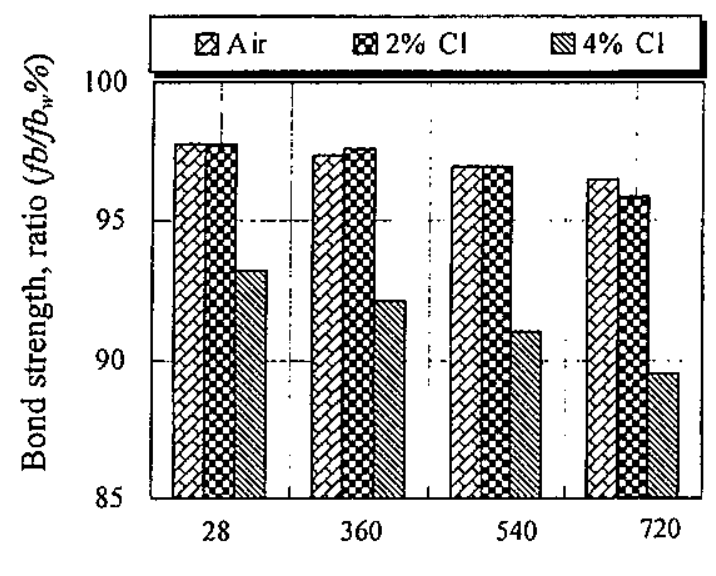

Curing age, days

Fig. 9 Rate of change in bond strength of HSC $\left(f b / f b_{w} \%\right)$ samples, with $10 \%$ SF addition cured in different media for long duration. 
M.M. El-Aiat, M.M.Balaha A.G. Abdel-Rahman, and H.E. Anwar, "Long-Term Behavior Of Silica Fume..."

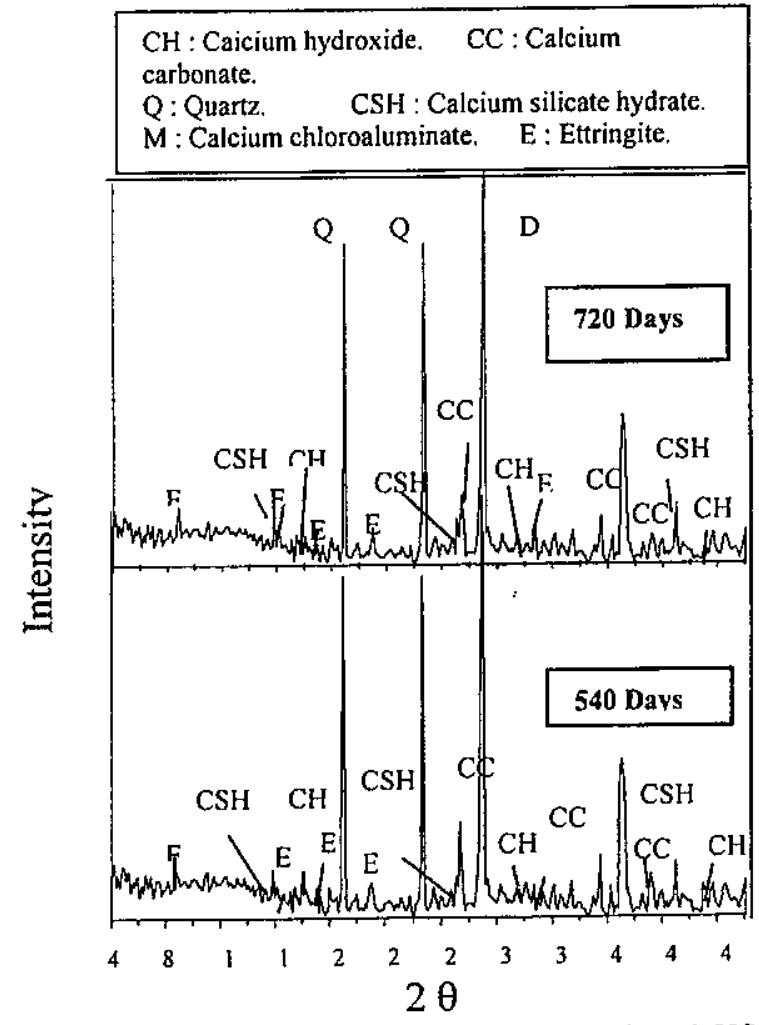

Fig. 10 X-Ray diffraction patterns of hardened HSC containing $10 \%$ silica fume cured in solution with $5 \% \mathrm{SO}_{4}$ up to 540 and 720 days

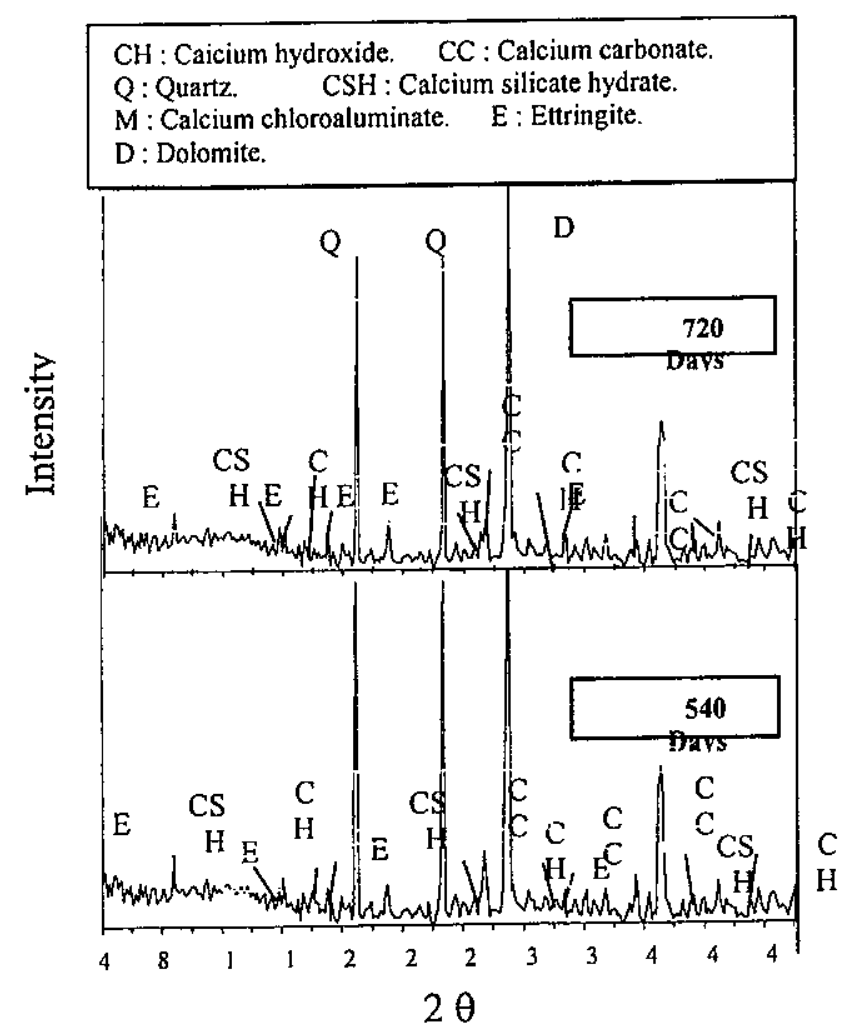

Fig. 11 X-Ray diffraction patterns of hardened HSC containing $10 \%$ silica fume cured in solution with $7 \% \mathrm{SO}_{4}$ up to 540 and 720 days
$\mathrm{CH}$ : Caicium hydroxide. $\mathrm{CC}:$ Calcium carbonate. $\mathrm{Q}:$ Quartz. CSH : Calcium silicate hydrate $M$ : Calcium chloroaluminate. E : Ettringite. D : Dolomite.

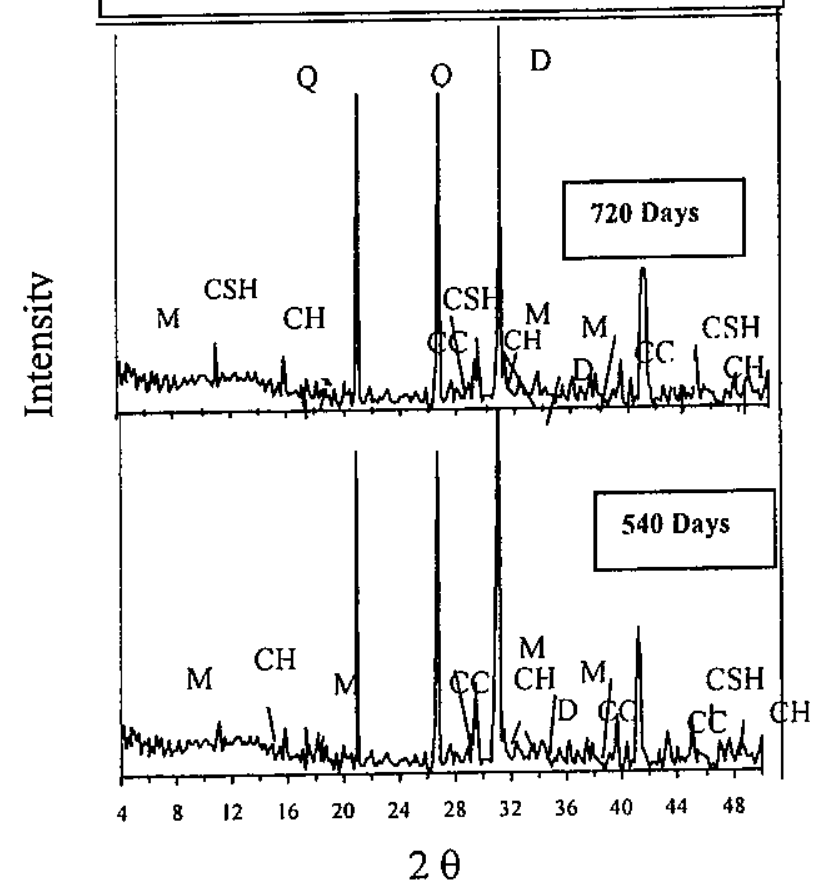

Fig. 12 X-Ray diffraction patterns of hardened HSC containing $10 \%$ silica fume cured in solution with $2 \% \mathrm{Cl}$ up to 540 and 720 days

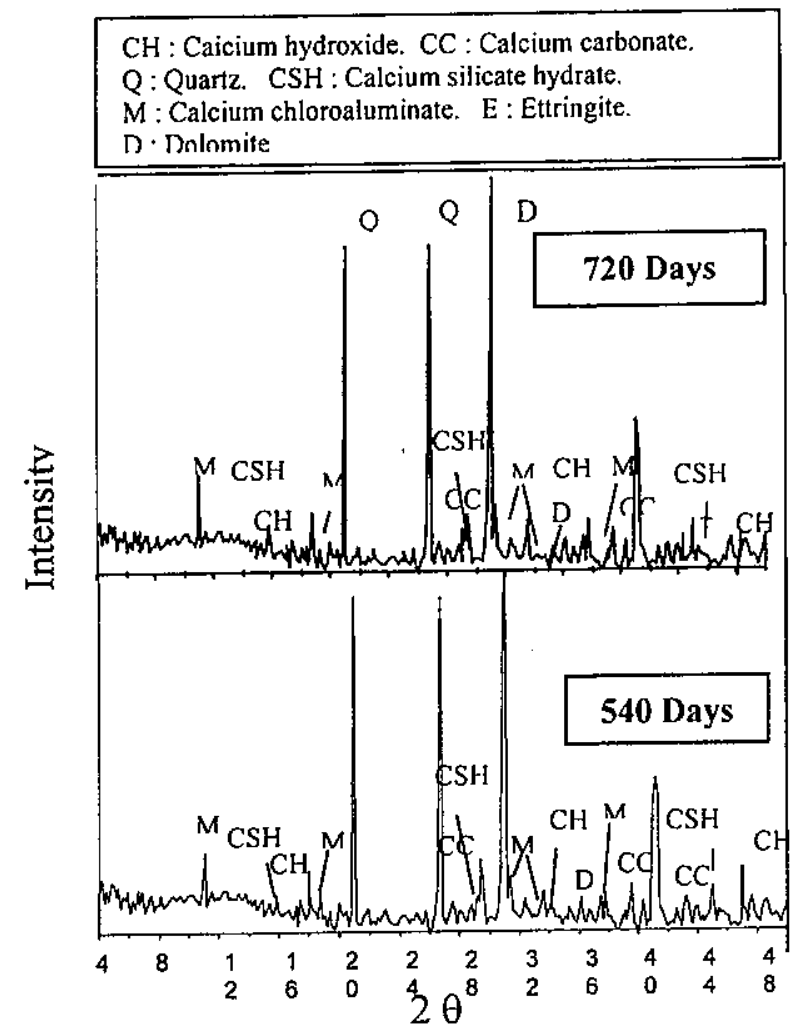

Fig. 13 X-Ray diffraction patterns of hardened HSC containing $10 \%$ silica fume cured in solution with $4 \% \mathrm{Cl}$ up to 540 and 720 days 
Finally, from the analysis of the test results represented in Figs. 1 to 9 and X-ray diffraction analysis it can be stated that the presence of chloride and sulphate ions in seawater together with magnesium and sodium ions would appear to constitute a major corrosion problem. High strength concrete has been observed to be severely damage by calcium chloride. Magnesium sulphate attacks most of the constituents of hydrated cement pastes and concrete.

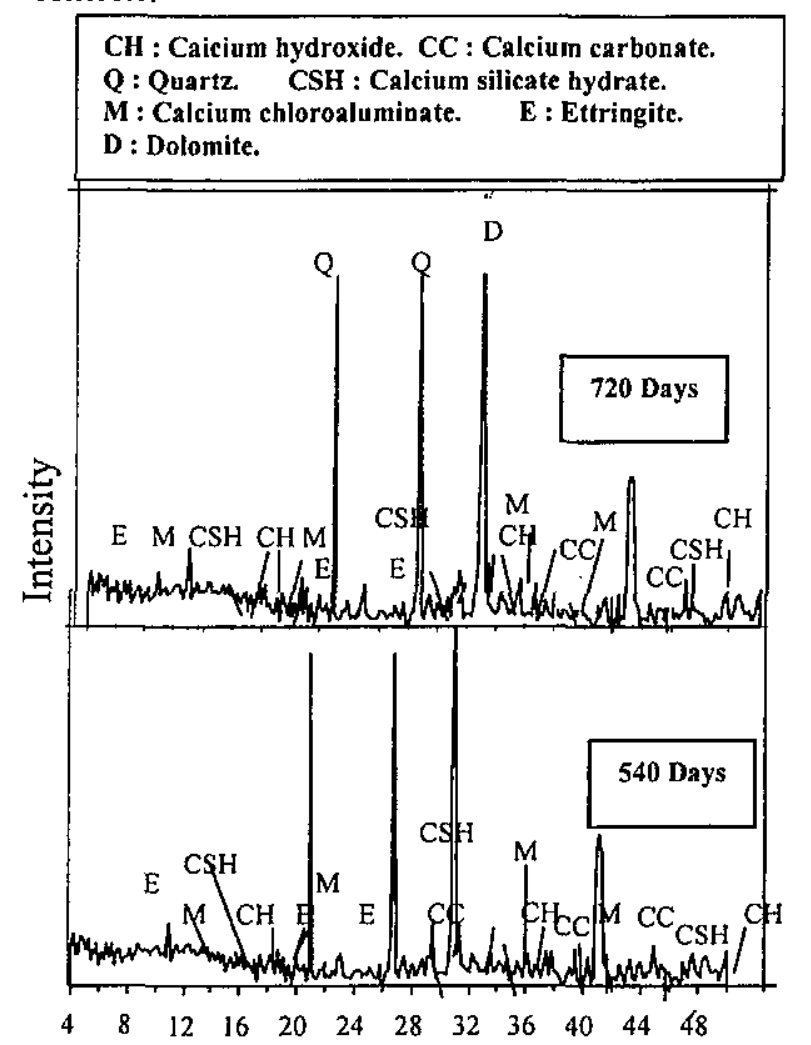

$2 \theta$

Fig. 14 X-Ray diffraction patterns of hardened HSC containing $10 \%$ silica fume cured in sea-water up to 540 and 720 days

It reacts with calcium aluminates ferrite hydrates to give calcium sulphoaluminate ferrite hydrates and $\mathrm{Mg}(\mathrm{OH})_{2}$. It also attacks calcium silicate hydrate to form gypsum, $\mathrm{Mg}(\mathrm{OH})_{2}$ and silica gel. Moreover, the resulting silica gel reacts very slowly with $\mathrm{Mg}(\mathrm{OH})_{2}$ to form hydrated magnesium silicate of an approximate composition of $4 \mathrm{MgO} . \mathrm{SiO}_{2} \cdot 8.5 \mathrm{H}_{2} \mathrm{O}$. The concrete strength is thereby decreased because magnesium silicate hydrate possesses no binding properties. $\mathrm{MgSO}_{4}$ of seawater dissolves more $\mathrm{Ca}(\mathrm{OH})_{2}$ in concrete than $\mathrm{Na}_{2} \mathrm{SO}_{4}$, resulting in an increase of porosity and, therefore, increase the attack. The presence of $\mathrm{NaCl}$ in seawater leads to dissolving both $\mathrm{Ca}(\mathrm{OH})_{2}$ and $\mathrm{Mg}(\mathrm{OH})_{2}$ more readily and this would justify the assumption of a more violent corrosion in seawater.

\section{CONCLUSIONS}

Based on the results of the study, the following conclusions were deduced:

( High strength concrete, (HSC) incorporating silica fume, when cured in air, exhibited some loss in strength, equal to about $10 \%$ from that cured in water.

2 HSC concrete recorded the highest values, higher rates of increase in the compressive strength up to 24 months compared with that of ordinary concrete for all aggressive media, and gives the best results especially at higher degrees of aggressiveness of the environment.

3 The durability of SF concrete is enhanced against sodium chloride and sodium sulphate. The resistance of silica fume blended cement to sulphate attack was attributed to the formation of fine pore structure, reducing lime content and a parallel decrease of the $\mathrm{Ca} / \mathrm{Si}$ ratio of the $\mathrm{CSH}$.

(4) The rate of attack on concrete by sulphate and chloride solutions depends on the solution concentration (degree of aggressiveness of the environment).

5 The XRD results indicated that the $\mathrm{Ca}(\mathrm{OH})_{2}$ and $\mathrm{CaCO}_{3}$ decreases with the addition of silica fume due to the higher pozzolanic activity of silica fume, which reacts with $\mathrm{Ca}(\mathrm{OH})_{2}$ and forms CSH.

6 The XRD results indicated that $\mathrm{CSH}$ peak intensities gradually decreased with chloride ion concentration. At the same time, the intensities of calcium chloroaluminate hydrate peaks are detected which is characteristic of the chemical reactions of sodium chloride and $\mathrm{Ca}(\mathrm{OH})_{2}$. These peaks are gradually decreased with silica fume addition and gradually increased with chloride ion concentration.

\section{REFERENCES}

[1] ACI Committee 234, "Guide for the Use of Silica Fume in Concrete", (ACI 234R-96), American Concrete Institute, Farmington Hills, Michigan, (1996).

[2] W.F. Price and JP. Hynes, "In-Situ Strength Testing of High Strength Concrete" Mag. Concr. Res., 48, No. 176, P.P.189-197, Sept., (1996).

[3] M.J. Paulo and K.E. Kimberly, "Time to Failure for Concrete Exposed to Severe Sulfate Attack", Cem. Concr. Res., 33 (7), 987-993, July (2003).

[4] E. Meck and V. Sirivivatnanon, "Field Indicator of Chloride Penetration Depth", Cem. Concr. Res., 33 (8), 1113-1117, August (2003).

[5] P.W. Brown and April Doerr, "Chemical Changes in Concrete Due to the Ingress of Aggressive species", Cem. Concr. Res., 30 (3), 339-505, March (2000).

[6] P. Castro, O.T. De Rincon and E.J. Pazini, "Interpretation of Chloride Profiles from Concrete Exposed to Tropical Marine 
Environments", Cem. Concr. Res., 31 (4), 529537, April (2001).

[7] M.M.M.Balaha, "Chemical Attack on Concrete", Review Article Prepared for Permanent Scientific Committee 56 for Structural \& Construction Engineering .June (2002).

[8] Bruce G.Smith, "Durability of Silica Fume Concrete Exposed to Chloride in Hot Climates" Journal of Materiais in Civil Engineering /January/February, P.P. 41-48, (2001).

[9] J. P. Bournzel and M. Moranville, "Durability of Concrete: The Crossroad Between Chemistry and Mechanics", Cem. Concr. Res., Vol., 27, No. 10, pp 1543-1552, (1997).

[10] M. Lachemi, G. Li, A. Tangnit-Haman, and P. C. Aitcin, "Long-Term Performance of Silica Fume Concretes", Concr. International, January, (1998).

[11] F. De Larrard and J.L. Bostuironnois, "On the Long-Term Strength Losses of Silica-Fume High Strength Concretes", Mag. Concr. Res., 43, No. 155, P.P.109-119, June, (1991).

[12] V. Mohan Malhotra, Min-Hong Zhang, Paul H. Read, and John Ryell, “ Long-Term Mechanical
Properties and Durability Characteristics of High-strength/ High- Performance Concrete Incorporating Supplementary Cementing Materials under Outdoor Exposure Conditions" ACI Materials Journal, V.97, No.5, SeptempberOctober, P.P. 518-525, (2000).

[13] Fahriye M. K., "Influence of $\mathrm{Na}_{2} \mathrm{SO}_{4}$ Solutions on the Capillary Absorption and Shrinkage of Mortars Made with Concrete Containing Silica Fume" Cem. Concr. Res., Vol. 27, No. 11, pp 1659-1665, (1997).

[14] F. M. Kilinckale, "The effect of $\mathrm{MgSO}_{4}$ and HCL solution on the Strength and Durability of Pozzolan Cement Mortars", Cem. Concr. Res., Vol. 27, No. 12, pp 1911-1918, (1997).

[15] H.F.W. Taylor, C. Famy and K.L. Scrivener, "Delayed Ettringite Formation", Cem. Concr. Res., 31 (5), 683-693, May (2001).

[16] W. Prince, M. Edwards-Lajnef and P.C. Aitcin, "Interaction Between Ettringite and a Polynaphthalene Sulfonate Superplasticizer in a Cementitious Paste", Cem. Concr. Res., 32 (1), 79-85, January (2002). 